\title{
Peningkatan Hasil Belajar Matematika dengan Menggunakan Model Problem Based Learning pada Siswa Kelas V Sekolah Dasar
}

\section{Umi Muslimah}

Universitas Sebelas Maret

Umi.muslimah94@gmail.com

\section{Article History}

received 30/4/2021

\begin{abstract}
The research aims to improve mathematics learning outcomes using a problem based learning model for fifth grade students of SD N Godog 02, Sukoharjo Regency in the 2020/2021 school year. This research is a Classroom Action Research (CAR). The research was carried out in two cycles, with each cycle consisting of planning, implementing actions, observing, and reflecting. Data collection techniques used in this study were observation and field notes. While the validity of the data using data triangulation techniques. Data analysis used quantitative analysis techniques and qualitative descriptions. The results showed that the results showed that through the application of the problem based learning model can improve student learning outcomes from the first cycle to the graduation percentage of $63 \%$ and in the second cycle the graduation percentage increased to $87 \%$. Based on the analysis and discussion of the research results, it can be concluded that the problem based learning model can improve mathematics learning outcomes for fifth grade students at SD N Godog 02, Sukoharjo Regency.
\end{abstract}

Keywords: Learning Outcomes, Mathematics, Problem Based Learning

\begin{abstract}
Abstrak
Penelitian ini bertujuan untuk meningkatkan hasil belajar matematika menggunakan model problem based learning pada siswa kelas V SD N Godog 02 Kabupaten Sukoharjo tahun pelajaran 2020/2021. Penelitian ini merupakan Penelitian Tindakan Kelas (PTK). Penelitian dilaksanakan dalam dua siklus, dengan tiap siklus terdiri atas perencanaan, pelaksanaan tindakan, observasi, dan refleksi. Teknik pengumpulan data yang digunakan dalam penelitian ini adalah observasi dan catatan lapangan. Sedangkan validitas data menggunakan teknik triangulasi data. Analisis data menggunakan teknik analisis kuantitatif dan diskribsi kualitatif. Hasil penelitian menunjukkan bahwa Hasil penelitian menunjukkan bahwa melalui penerapan model problem based learning dapat meningkatkan hasil belajar siswa dari ke siklus I dengan persentase kelulusan sebesar $63 \%$ dan pada siklus 2 mengalami kenaikan persentase kelulusan menjadi $87 \%$. Berdasarkan analisis dan pembahasan hasil penelitian dapat disimpulkan bahwa model problem based learning dapat meningkatkan hasil belajar matematika siswa kelas V SD N Godog 02 Kabupaten Sukoharjo.
\end{abstract}

Kata kunci: Hasil belajar, Matematika, Problem Based Learning 


\section{PENDAHULUAN}

Meningkatknya kasus corona di Indonesia memberikan dampak sendiri bagi dunia pendidikan. Pembelajaran yang semulanya dilaksanakan secara tatap muka kini harus dilaksanakan secara jarak jauh. Sesuai dengan Surat Edaran Mendikbud Nomor 4 tahun 2020 tentang pelaksanaan kebijakan pendidikan dalam masa darurat penyebaran corona virus disease (Covid-19) menganjurkan untuk melaksanakan proses belajar dari rumah melalui pembelajaran daring. Dalam pelaksanaan kegiatan daring tentunya memberikan tantangan kepada guru untuk berinovasi menentukan model pembelajaran yang tepat. Selain itu siswa juga harus siap dengan kegiatan pembelajaran yang berbeda dari sebelumnya yaitu dengan kegiatan pembelajaran daring. Mastusti, dkk (2020: 65) menyatakan bahwa pembelajaran daring membawa perubahan cara mengajar sehingga guru dan siswa beradaptasi dari pembelajaran secara tatap muka di kelas menjadi pembelajaran daring.

Tidak hanya dalam kegiatan tatap muka saja, tetapi dalam pembelajaran yang dilaksanakan secara daring, aktivitas pembelajaran harus mampu mengembangkan keterampilan 4C yaitu critical thinking, creativity, collaboration, dan communication. Agar keterampilan 4C berkembang dengan baik maka perlu proses pembelajaran yang optimal sehingga mendapatkan hasil belajar yang maksimal.

Hasil belajar merupakan hasil belajar merupakan perubahan tingkah laku individu dari yang belum bisa mejadi bisa yang mencakup tiga aspek yaitu kognitif, afektif, dan psikomotorik. Menurut Suprihatiningrum (2013: 38-45) garis besar indikator penilaian hasil belajar dibagi menjadi 3 aspek, yakni kognitif, afektif dan psikomotorik. Salah satu hasil belajar yang dinilai guru di kelas V SD adalah mata pelajaran Matematika. Di kelas V SD Matematika merupakan mata pelajaran yang berdiri sendiri, tidak terintegrasi kedalam tema seperti IPS, IPA, Bahasa Indonesia dan PJOK.

Matematika merupakan pembelajaran yang bersifat numerik yang merupakan ilmu pasti, sehingga dalam pemecahannya harus menggunakan cara berpikir logis dan kritis. Ibrahim dkk (2012: 35) menyatakan bahwa mata pelajaran matematika memiliki tujuan, antara lain yaitu untuk membekali siswa dengan kemampuan berpikir logis, analitis, sistematis, kritis, dan kreatif, serta kemampuan bekerjasama. Cara berpikir kritis dan logis merupakan salah satu aspek kognitif yang berpengaruh terhadap hasil belajar siswa.

Berdsarkan hasil observasi hasil belajar siswa di SD N Godog 02 khususnya kelas $\mathrm{V}$ masih rendah. Keadaan tersebut terbukti dari kegiatan pembelajaran bahwa siswa cenderung pasif ketika guru memberikan sebuah pertanyaan. Guru harus menunjuk salah satu siswa untuk menjawab pertanyaan. Hasil jawaban siswa pun juga menunjukkan bahwa jawaban mereka hanya sebatas jawaban singkat yang belum didasari dengan pemikiran yang kritis dan logis. Lebih jauh lagi dalam jenis soal cerita, siswa kurang memahami masalah dan merumuskannya. Hal itu berdampak pada hasil ulangan matematika yang menunjukkan sebesar $42 \%$ siswa mendapatkan nilai di atas KKM, sedangkan siswa yang mendapatkan nilai dibawah KKM sebesar 58\%. Maka berdasarkan permasalahan yang ditemukan diperlukan model pembelajaran yang tepat yang mampu membantu siswa untuk berpikir kritis dan logis sehingga hasil belajar dapat meningkat.

Salah satu model pembelajaran yang dapat diterapkan guru adalah model Problem Based Learning. Model Problem Based Learning merupakan model pembelajaran yang melibatkan siswa dalam proses pemecahan masalah sehingga siswa belajar berpikir kritis. Ngalimun (2013: 90) menyatakan bahwa model PBL merupakan model pembelajaran yang fokus pembelajaran ada pada masalah yang dipilih sehingga siswa memperoleh pengalaman belajar yang berhubungan dengan keterampilan menerapkan metode ilmiah dalam pemecahan masalah dan menumbuhkan pola berpikir kritis. 
Melalui penerapan model Prolem Based Learning yang melibatkan siswa untuk memecahkan dan berpikir kritis maka kegiatan tersebut akan berdampak pada hasil belajar yang meningkat. Sebagaimana penelitian yang dilakukan oleh Himawan, $R$ (2014) dalam jurnalnya yang berjudul Meningkatkan Hasil Belajar Matematika Materi Pengolahan Data Menggunakan Model Problem Based Learning Siswa Kelas Vi Sdn Kedungrawan I Krembung Sidoarjo menyatakan bahwa Model Problem Based Learning dapat meningkatkan hasil belajar siswa dengan ketuntasan belajar pada siklus I sebesar $20 \%$ dan meningkat pada siklus II menjadi $80 \%$.

\section{METODE}

Penelitian ini merupakan Penelitian Tindakan Kelas (PTK) dengan model spiral yang saling berkaitan. Polpulasi penelitian ini adalah siswa kelas V SD N Godog 02 tahun pelajaran 2020/2021 sebanyak 24 siswa dengan rincian 11 siswa perempuan dan 13 siswa laki-laki.

Teknik pengumpulan data dengan menggunakan tes dan nontes. Teknik tes berupa lembar evaluasi tertulis berupa pilihan ganda dan uraian untuk mendapatkan data hasil belajar matematika. Teknik nontes digunakan untuk mendapatkan data penerapan model problem based learning terhadap siswa dan guru. Teknik non tes yang digunakan yaitu: 1) Lembar observasi yang digunakan untuk mengamati kegiatan siswa dan tindakan guru selama berlangsungnya pembelajaran dengan menggunakan model problem based learning. 2) catatan lapangan yang digunakan oleh peneliti untuk menggambarkan dan melaporkan hasil pengamatan pada saat proses pembelajaran model problem based learning, suasana kelas, pengelolaan kelas. Dengan menggunakan catatan lapangan guru dapat mengetahui hambatan dan kekurangan untuk perbaikan pada pertemuan berikutnya.

Teknik analisis data yang digunakan yaitu dengan analisis kualitatif dan analisis kuantitatif. Analisis kualitatif digunakan untuk menganalisis hasil observasi pada siswa dan guru dalam pembelajaran yang menggunakan model problem based learning. Analisis kuantitatif digunakan untuk menganalisis hasil belajar siswa.

\section{HASIL DAN PEMBAHASAN}

Penelitian dilakukan dengan menggunakan lembar observasi yang diberikan kepada 2 orang observer yaitu teman sejawat/guru. Persentase aktifitas pembelajaran siswa dengan menggunakan model Problem Based Learning.

Tabel 1. Hasil Pengamatan Penerapan Model Problem Based Learning Terhadap Siswa Pada Siklus I dan Siklus 2

\begin{tabular}{lcccc}
\hline \multicolumn{1}{c}{ Aspek } & \multicolumn{3}{c}{ Siklus } & Kategori \\
\hline & I & II & Rata-rata & \\
\hline Merumuskan masalah & $75 \%$ & $85 \%$ & $80 \%$ & Baik \\
\hline Menganalisis masalah & $68,75 \%$ & $82 \%$ & $75,4 \%$ & Baik \\
\hline Merumuskan hipotesis & $75 \%$ & $84 \%$ & $79,5 \%$ & Baik \\
\hline Mengumpulkan data & $87,5 \%$ & $86 \%$ & $86,7 \%$ & Sangat Baik \\
\hline Mengujian hipotesis & $68,75 \%$ & $84 \%$ & $76,4 \%$ & Baik \\
\hline $\begin{array}{l}\text { Merumuskan rekomendasi } \\
\text { pemecahan masalah }\end{array}$ & $71,87 \%$ & $82 \%$ & $76,6 \%$ & Baik \\
\hline Rata - Rata & $74,47 \%$ & $83 \%$ & $78,7 \%$ & Baik \\
\hline
\end{tabular}

Tingkat keberhasilan:

$86 \%-100 \%=$ Sangat baik

$75 \%-85 \%=$ Baik
$55 \%-59 \%=$ Kurang

$\geq 54 \% \quad=$ Kurang Sekali 
$60 \%-74 \%=$ Cukup

Berdasarkan tabel 1 di atas disiklus 1 hasil aktititas siswa dalam penerapan pembelajaran model Problem Based Learning adalah sebesar $74,47 \%$ dan terjadi kenaikan pada siklus II sebesar $78,7 \%$. Pada tabel selanjutkan akan disajikan data pengamatan hasil pengamatan terhadap guru dalam penerapan model Problem Based Learning pada siklus I dan siklus II.

Tabel 2. Hasil Pengamatan Penerapan Model Problem Based Learning Terhadap Guru Pada Siklus I dan Siklus 2

\begin{tabular}{lcccc}
\hline \multicolumn{1}{c}{ Aspek } & \multicolumn{3}{c}{ Siklus } & Kategori \\
\hline \multicolumn{1}{c}{ Merumuskan masalah } & $78,12 \%$ & $80 \%$ & $79.06 \%$ & Baik \\
\hline Menganalisis masalah & $68,75 \%$ & $87 \%$ & $77,8 \%$ & Baik \\
\hline Merumuskan hipotesis & $78,12 \%$ & $87 \%$ & $82,56 \%$ & Baik \\
\hline Mengumpulkan data & $75 \%$ & $87 \%$ & $81 \%$ & Baik \\
\hline Mengujian hipotesis & $81,25 \%$ & $81 \%$ & $81,1 \%$ & Baik \\
\hline $\begin{array}{l}\text { Merumuskan rekomendasi } \\
\text { pemecahan masalah }\end{array}$ & $69,37 \%$ & $93 \%$ & $81,2 \%$ & Baik \\
\hline $\begin{array}{l}\text { Rata - Rata } \\
\text { Rata }\end{array}$ & $69,79 \%$ & $87,5 \%$ & $80,45 \%$ & Baik \\
\hline
\end{tabular}

Tingkat keberhasilan:

$$
\begin{array}{llll}
86 \%-100 \% & =\text { Sangat baik } & 55 \%-59 \% & =\text { Kurang } \\
75 \%-85 \% & =\text { Baik } & \geq 54 \% & =\text { Kurang Sekali } \\
60 \%-74 \% & =\text { Cukup } & &
\end{array}
$$

Berdasarkan tabel 2 di atas disiklus 1 hasil aktititas guru dalam penerapan pembelajaran model Problem Based Learning adalah sebesar 69,79\% dan terjadi kenaikan pada siklus II sebesar $87,5 \%$. Hasil belajar siswa juga disajikan dalam bentuk tabel berikut.

Tabel 3. Perbandingan dan Persentase Hasil Belajar Siswa Siklus I dan II

\begin{tabular}{ccc}
\hline & Siklus I & Siklus II \\
\hline Perbandingan Hasil Belajar & 70 & 81 \\
& & \\
\hline Persentase Hasil Belajar & $63 \%$ & $87 \%$
\end{tabular}




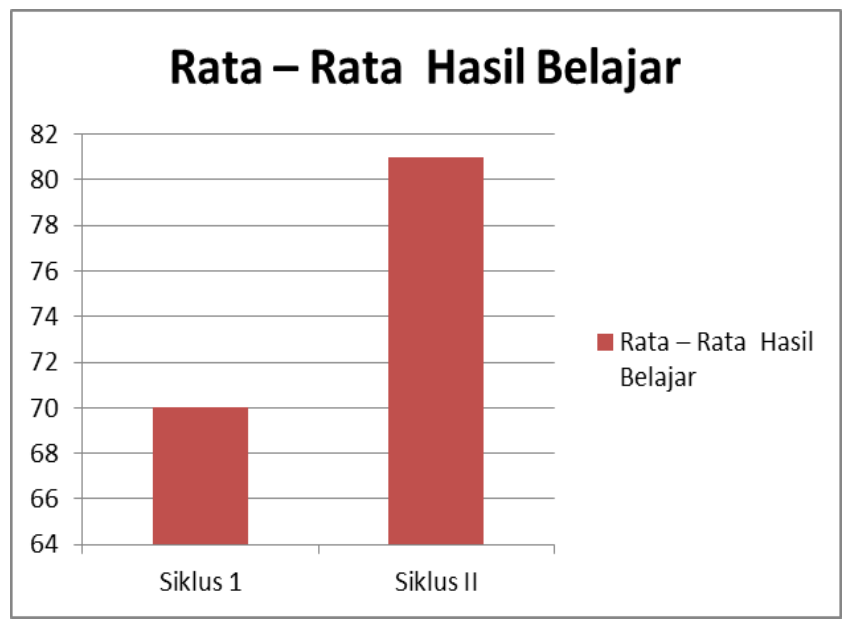

Gambar 1. Hasil Belajar Siswa Siklus I dan II

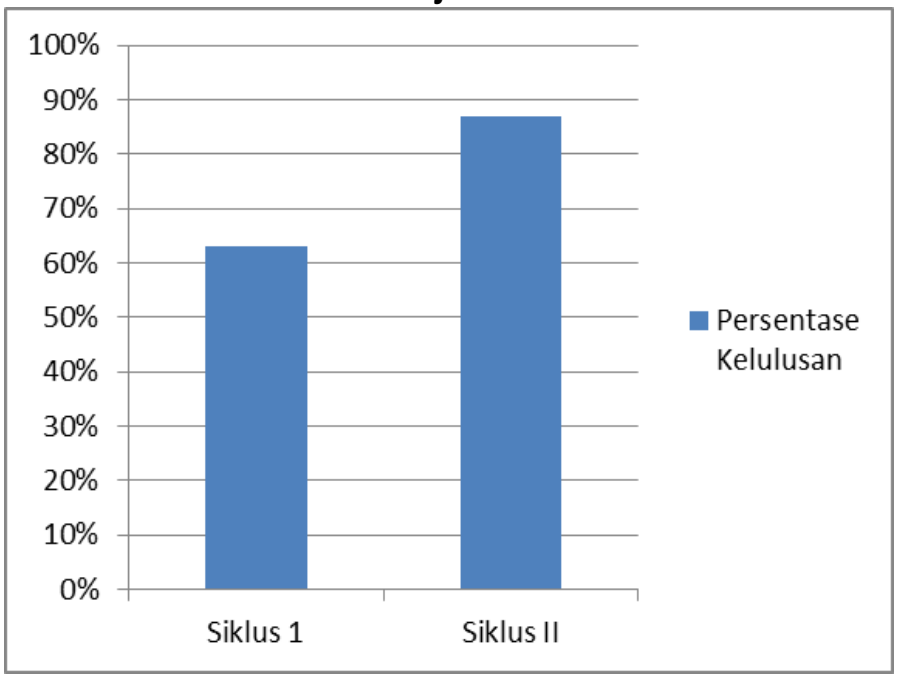

Gambar 2. Persentase Hasil Belajar Siswa Siklus I dan II

Berdasarkan hasil analisis pengamatan selama pembelajaran dengan menerapkan model problem based learning menunjukkan bahwa proses pembelajaran pada siklus I dan II mengalami peningkatan. Hasil pengamatan penerapan model problem based learning terhadap guru pada siklus I adalah $69,79 \%$. Pada siklus II hasil pengamatan penerapan model problem based learning terhadap Guru Siklus II mengalami peningkatan menjadi $87,5 \%$. Hasil pengamatan penerapan model problem based learning terhadap siswa pada siklus I adalah $74,74 \%$. Hasil pengamatan penerapan model problem based learning terhadap siswa pada siklus II mengalami peningkatan menjadi $83 \%$.

Keberhasilan peningkatan aktivitas penerapan model problem based learning juga tidak lepas dari langkah - langkah pelaksanaan pembelajaran. Adapun langkah langkah yang telah terlaksana sebagai berikut:

1. Merumuskan masalah

Pada siklus I kegiatan siswa yaitu mengamati gambar yang ada pada slide power point. Gambar tersebut menunjukkan adanya empat orang anak yang melakukan pengukuran dan memiliki tinggi badan yang berbeda. Guru memberikan stimulasi siswa untuk mencoba marumuskan masalah. Pada siklus II siswa memahami soal cerita mengenai cita-cita teman satu kelas yang disajikan guru. Guru memberikan stimulasi siswa untuk mencoba marumuskan masalah dari kasus soal cerita tersebut dengan memberikan beberapa pertanyaan 
2. Menganalisis masalah

Pada siklus I siswa dibimbing guru untuk meninjau kembali masalah dari gambar yang telah dipaparkan guru secara kritis. Siswa menganalisis tujuan adanya pengukuran tinggi badan sehingga dapat diperoleh suatu data. Pada langkah ini guru membimbing siswa untuk memperoleh informasi tentang apa itu data dan jenis data. Pada siklus II siswa menelaah pertanyaan pematik yang diberikan guru berdasarkan tabel lembar isian yang disajikan dalam halaman google site.

3. Merumuskan hipotesis

Pada siklus I siswa menyampaikan kemungkinan jawaban tentang jenis data. Guru membimbing siswa untuk menyampaikan pendapatnya satu persatu tentang jenis data.

4. Mengumpulkan data

Pada siklus I kegiatan siswa yaitu menahami perintah di LKPD yang telah dibagikan guru melalui layar googlemeet. Guru membimbing siswa dengan menjelaskan kembali langkah demi langkah yang harus siswa lakukan untuk memecahkan masalah yang tersaji dalam LKPD. Pada siklus II siswa dengan bimbingan guru merumuskan hipotesis dengan membuat 5 pertanyaan. Sebelum siswa membuat pertanyaan, siswa diberikan contoh pertanyaan yang berkaitan dengan masalah,

5. Mengujian hipotesis

Pada siklus I guru membimbing siswa untuk merumuskan kemungkinan jawaban dari pengumpulan data yang telah siswa lakukan. Siswa menjawab 5 point pertanyaan yang ada pada LKPD sebagai bahan pendukung merumuskan hipotesis yang muncul. Pada siklus II dengan memanfaatkan grup WA siswa mengumpulkan data tentang hobi dan cita - cita teman sekelasnya

6. Merumuskan rekomendasi pemecahan masalah.

Pada siklus I siswa dengan bimbingan guru mencoba merumuskan kesimpulan berdasarkan hasil pengumpulan data. Siswa menyimpulkan perbedaan antara jenis data primer dan jenis data skunder. Pada siklus II Siswa menggambarkan langkah yang sesuai rumusan hasil pengujian. Siswa menyusun laporan pengumpulan data yang dilakukan dan dihasil laporan.

Penerapan model problem based learning pada mata pelajaran matematika membawa dampak pada peningkatan hasil belajar siswa kelas V. Setelah dilaksanakan tindakan pembelajaran, diketahui bahwa pelaksanaan siklus I dan siklus II mengalami peningkatan. Pada siklus I terjadi peningkatan ketuntasan belajar sebesar $63 \%$ dengan rata - rata kelas sebesar 70 . Pada siklus II terjadi peningkatan ketuntasan belajar menjadi $87 \%$ dengan rata - rata kelas sebesar 81 . Hasil siklus II ini sudah mencapai target ketuntasan yang telah ditetapkan yaitu sebesar $80 \%$ dengan KKM 70, jadi pada siklus II ini pelaksanaan tindakan dihentikan. Penelitian ini sejalan dengan hasil penelitan yang dilkukan oleh Puspita, dkk (2018) menyatakan bahwa penerapan model problem based learning pada mata pelajaran matematika SD efektif dapat meningkatkan hasil belajar siswa dari siklus I 63\% meningkat menjadi 83\% pada siklus II.

Berdasarkan hasil yang telah didapatkan model problem based learning terbukti dapat meningkatkan hasil belajar matematika kelas V SD N Godog 02. Abidin (2014: 161) menyatakan bahwa PBL mendorong siswa agar mampu berfikir tingkat tinggi, analisis, sintesis, dan evaluasi sehingga siswa memperoleh penguasaan pengetahuan, keterampilan dan sikap. Dengan penerapan model problem based learning siswa akan terbiasa dengan permasalahan yang membutuhkan cara berpikir kritis dan logis sehingga mendorong meningkatnya hasil belajar.

Selama pembelajaran matematika berlangsung siswa diberi kesempatan untuk mencari sebuah permasalahan untuk dipecahkan. Siswa secara mandiri berusaha menemukan cara pemecahan masalahnya. Dalam penerapan model problem based 
learning siswa memperoleh pengetahuan baru berdasarkan permasalahan yang siswa pecahkan. Siswa mencari sebuah Triyanto (2014: 94-96) menyatakan bahwa melalui model problem based learning siswa dapat menciptakan pengetahuan dan keterampilan siswa agar dapat berpikir logis terhadap ide-ide dalam memecahkan suatu permasalahan. Jadi dalam pembelajaran siswa memperoleh ide tidak dari satu arah saja yaitu guru, melainkan siswa membangun sendiri pengetahuan dan keterampilan melalui kegiatan pemecahan masalah.

\section{SIMPULAN}

Model problem based learning untuk meningkatkan hasil belajar matematika materi statistika pada kelas $\mathrm{V}$ memberikan peningkatan pada hasil belajar siswa. Hal ini terbukti pada kenaikan persentasi kelulusan dan rata - rata pada siklus I dan siklus II. Pada siklus I persentase kelulusan yang didapatkan siswa adalah sebesar $63 \%$ dengan rata - rata nilai 70 . Hasil peningkatan terlihat pada siklus II dengan kenaikan persentase menjadi $87 \%$ dengan rata - rata nilai sebesar 81 .

Implikasi dan tindak lanjut untuk penelitian ini adalah sebagai berikut: 1. guru dapat mengimplikasikan ilmunya dengan mensosialisasikan model problem based learing kepada rekan guru lainnya, 2. Sekolah dapat meningkatkan sarana dan prasarana untuk mendukung guru - guru dalam mengembangkan model problem based learning sehingga proses pembelajaran dapat berjalan efektif dan efisien, 3 . Siswa dapat terlibat dalam sebuah permasalahan sehingga siswa terbiasa dengan cara berpikir kritis dalam memecahkan masalah secara nyata.

\section{DAFTAR PUSTAKA}

Abidin. (2014). Desain Sistem Pembelajaran dalam Konteks Kurikulum 2013. Bandung: Refika Aditama.

Ibrahim, dkk. (2012). Pembelajaran Matematika Teori dan Aplikasinya. Yogyakrta: SUKA-Press UIN Sunan Kalijaga.

Himawan, R. (2014). Meningkatkan Hasil Belajar Matematika Materi Pengolahan Data Menggunakan Model Problem Based Learning Siswa Kelas Vi Sdn Kedungrawan I Krembung Sidoarjo. Jurnal PGSD. 02 (2). 13

Mastuti, dkk. (2020). Teaching From Home: dari Belajar Merdeka menuju Merdeka Belajar. Jakarta: Yayasan Kita Menulis

Ngalimun. (2013). Stategi dan Model Pembelajaran. Yogyakarta: Aswaja Pressindo.

Puspita, M, dkk (2018). Peningkatan Hasil Belajar Matematika Siswa Kelas 4 SD Melalui Model Pembelajaran

Kementrian Pendidikan dan Kebudayaan.(2020). Surat Edaran Mendikbud Nomor 4, tahun 2020, tentang pelaksanaan kebijakan pendidikan dalam masa darurat penyebaran corona virus disease (Covid-19)

Suprihatiningrum, J.(2013). Strategi Pembelajaran: Teori dan Aplikasi. Yogyakarta: ArRuzz Media.Problem Based Learning. Jurnal Sains dan Teknologi. 01 (1). 120-125

Trianto .(2014). Model Pembelajaran Terpadu. Jakarta: PT.Bumi Aksara 